\title{
Effect of Plant Growth Promoting Rhizobacteria (PGPR) on Increasing the Activity of Defense Enzymes in Tomato Plants
}

\author{
Fadhila Rahmi Joni ${ }^{1}$, Hasmiandy Hamid ${ }^{2}$, Yulmira Yanti ${ }^{2}$
}

\author{
${ }^{1}$ Post Graduated of Faculty of Agriculture, Andalas University, Padang, West Sumatera, Indonesia \\ ${ }^{2}$ Department of Plant Protection, Faculty of Agriculture, Andalas university. Limau Manis, Pauh, Padang, West Sumatera, Indonesia
}

Received:6 Oct 2020; Received in revised form: 13 Nov 2020; Accepted: 14 Nov 2020; Available online: 17 Nov 2020

\begin{abstract}
Growth-promoting rhizobacteria are non-pathogenic bacteria that can induce plant defense through induction of systemic resistance which can then activate defense enzymes such as Polyphenol Oxidase (PPO), Peroxidase (PO) and Penil Alanine Amoliase (PAL). This study aims to determine the activity of the PPO, PO and PAL defense enzymes with selected PGPR isolates. This research was carried out at the Microbiology and Greenhouse Laboratory of the Faculty of Agriculture, Andalas University, Padang, and then tested at the PAU IPB Laboratory, West Java Indonesia in March-July 2020. The results showed that tomato leaves that had been treated with PGPR showed that PGPR had the potential to increase the PO enzyme $0.072 \mu \mathrm{g} \cdot m L-1$, PPO $0.0009 \mu \mathrm{g} \cdot m L-1$ and PAL $14.15 \mu \mathrm{g} \cdot \mathrm{mL}-1$. EAB 2.1 isolate is best isolate can increase PPO, PO and PAL.
\end{abstract}

Keywords-PGPR, PPO, PO, PAL.

\section{INTRODUCTION}

PGPR is a non-pathogenic microbe that can increase plant fertility and induce plant resistance from biotic and abiotic stresses through the ISR mechanism. Plant Growth Promoting Rhizobacteria (PGPR) is a group of soilspecific microorganisms that efficiently colonize rhizosphere and rhizoplan and can substantially improve plant health (Hatami and Ghorbanpour, 2016). Specific mechanisms between PGPR and plant pests and pathogens are by producing antibiotics, competition of substrate and ecological niches, siderophores, chitinase enzymes, $\beta-1,3-$ glucanase, cyanide, parasitism, and inducing systemic plant resistance (ISR) in the host. (Khalimi and Wirya. 2009).

ISR is an effective defense mechanism manifested as a result of physiological changes in plants, such as modifications to the cell wall structure and the synthesis of antimicrobial compounds such as proteins associated with pathogenesis (PR) and phytoalexins, which wreak the spread of pathogens (Filippi et al., 2011). Antioxidant enzymes such as peroxidase (PO), phenylalanine amonialyase (PAL) and polyphenol oxidase (PPO) may be enzymes elicited by ISR (Yasmin et al., 2016). Induced systemic resistance (ISR) involves the production of oxidative enzymes such as peroxidase (PO) and polyphenol oxidase (PPO), which catalyzes the formation of lignin, and other oxidative phenols that contribute to the formation of defenses (Meziane et al., 2005; Jetiyanon, 2007). PGPR can stimulate systemic responses in tomatoes by inducing the activity of defense enzymes such as phenylalanine ammonialyase (PAL), peroxidase (PO), polyphenol oxidase (PPO) and chitinase as well as the level of phenolic accumulation which further reduces infection by biotic pressure (Ahmed et al., 2011) .

Several studies have shown the ability of PGPR to increase the activity of defense enzymes in plants, including cucumber roots treated with Pseudomonas corrugata 13 or Pseudomonas aureofaciens 63-28 can increase phenylalanine ammonia-lyase (PAL) activities, peroxidase (PPO) and polyphenol oxidase (PO) activity (Chen et al 2000). Turmeric plants introduced with Bacillus amyloliquefaciens BaTNAU5 and Pseudomonas fluorescens strain Pf3TNAU triggered an increase defense enzymes peroxidase (PO), polyphenol oxidase (PPO), phenylalanine ammonia lyase (PAL), $\beta$-1,3-glucanase, chitinase, catalase and chemicals that trigger defense (total phenol) (Adhipati et al., 2014). In previous studies, there 
were 3 root bacteria and 4 endophytic bacteria which were able to suppress whitefly populations and tomato wilt disease (Yanti 2018 and Hamid 2020). This study aims to determine the activity of the PPO, PO and PAL defense enzymes with selected PGPR isolates.

\section{MATERIALS AND METHODS}

The research was carried out in the Microbiology laboratory and greenhouses of the Faculty of Agriculture, Andalas University, Padang. Subsequently, a defense enzyme analysis was carried out at the PAU IPB Bogor Laboratory, West Java, Indonesia from March to July 2020.

\section{Rejuvenation and Propagation of Rhizobacterial Isolates}

Rhizobacterial isolates were obtained from the Yanti collection (2017). Rhizobacterial isolates were rejuvenated by means of one ose of bacteria transferred to NA medium in a Petri dish by the scratch method and incubated at room temperature for $2 \times 24$ hours. Furthermore, rhizobacterial multiplication was carried out consisting of 2 stages: (1) pre-culture, 1 rhizobacterial colony from pure culture was transferred into $10 \mathrm{ml} \mathrm{NB}$ medium in culture bottles and incubated on a rotary shaker at a speed of 150 rpm for 24 hours at room temperature. (2) Main-culture, 1 $\mathrm{ml}$ of suspension from preculture was transferred into 25 $\mathrm{ml}$ of sterile coconut water in a culture bottle and incubated in the same manner for $2 \times 24$ hours (Habazar et al., 2007). Rhizobacterial suspension from main-culture was determined by population density based on comparison with McFarland scale $8\left(\mathrm{BaCl} \mathrm{0,8} \mathrm{g}+\mathrm{H}_{2} \mathrm{SO}_{4}\right.$ $1 \%$ 9,2 g) (bacterial population density estimated at $10^{8}$ cells/ml) (Klement et al., 1990).

\section{Preparation of Planting Media}

Tomato growing media is a mixture of soil and sterile manure with a ratio of $2: 1$. The mixture of soil and manure is sterilized for 1 hour at $100^{\circ} \mathrm{C}$ in a container measuring $45 \times 40 \mathrm{~cm} 2$, then refrigerated for 24 hours. For the nursery, the soil is put into a pot-tray 22 grams / hole, while for planting chilies, the soil is put in a $4 \mathrm{~kg} /$ polybag

\section{Introduction of rhizobacterial isolates}

Rhizobacterial isolates was introduced twice, namely to seeds and seedlings.

Tomato seeds used are Warani Varieties. Tomato seeds are surface sterilized by soaking them in a $1 \%$ sodium hypochlorite solution for 3 minutes, after which they are drained and rinsed with distilled water 2 times and then dried. The seeds are soaked in rhizobacterial suspension for 15 minutes then planted in a pot-tray. Seedlings are maintained for 21 days.

Tomato seedlings that are 21 days old are transferred to polybags that have a mixture of sterilized soil and manure. Before planting, the roots are cleaned from the rest of the previous planting media and then immersed in rhizobacterial suspension for 15 minutes, then pla-nting

\section{Measurement of Plant Defense Enzyme Activity}

\section{i. Peroxidase (PO)}

The peroxidase enzyme activity test was performed by the Yanti method (2015). $1 \mathrm{~g}$ roots and stems macerated, then added $2.5 \mathrm{~mL}$ Potassium phosphate $0.5 \%$ buffer $\mathrm{pH} 7$ and $0.1 \mathrm{~g}$ Polyvinyl pyrplidone (PVP). The suspension is homogenized and filtered using two layers of gauze, then centrifuged at a speed of $6,000 \mathrm{rpm}(60 \mathrm{rpm}=1 \mathrm{~Hz})$ for 15 minutes at $4^{\circ} \mathrm{C}$. Supernatants are used to measure peroxidase activity.

Peroxidase activity measurements were carried out based on the Bateman method (1967). An enzyme extraction of $0.2 \mathrm{~mL}$ was added to a cup containing $5 \mathrm{~mL}$ pyrogallol (0.631 g pyrogallol in $0.005 \mathrm{M}$ phosphate buffer $\mathrm{pH}$ 6, final volume $100 \mathrm{~mL}$ ) and then shaken. The cup was placed on a spectrophotometer with $420 \mathrm{~nm}$ absorbance. $0.5 \mathrm{~mL}$ of $1 \% \mathrm{H}_{2} \mathrm{O}_{2}$ is added to the cup, then shaken and immediately placed on a spectrophotometer. Changes in absorbance are observed every 5 seconds until there is no change. Peroxidase activity is expressed in $\mu \mathrm{g} / \mathrm{mL}$.

\section{ii. Polyphenol oxidase (PPO)}

$1 \mathrm{~g}$ root and stem tissue samples were crushed and dissolved in $2 \mathrm{~mL}$ cold $50 \mathrm{mM}$ phosphate buffer $\mathrm{pH}$ 6.5. The filtrate was then centrifuged at $16,000 \mathrm{~g}$ for 15 minutes at $4^{\circ} \mathrm{C}$. The resulting filtrate is used as a source of enzymes. A $2.6 \mathrm{~mL}$ phosphate buffer solution $\mathrm{pH} 6.5$ of $2.6 \mathrm{~mL}, 0.1 \mathrm{~mL} \mathrm{~L}-3,4$-dihydroxyphenylalanine (L-DOPA) $5 \mathrm{mM}, 0.1 \mathrm{~mL}$ ascorbic acid $2.1 \mathrm{mM}$, and $1 \mathrm{~mL}$ EDTA $0.065 \mathrm{mM}$ is mixed until homogeneous. A crude enzyme of $0.1 \mathrm{~mL}$ was added to the solution and incubated for 10 minutes at room temperature. The solution was then measured for absorbance at a wavelength of $265 \mathrm{~nm}$ with a spectrophotometer (Karthikeyan et al., 2006).

\section{iii. Phenylalanine Ammonia Lyase (PAL)}

$1 \mathrm{~g}$ of leaf tissue samples were crushed and dissolved in $2 \mathrm{ml}$ of cold $0.1 \mathrm{M}$ sodium borate buffer $\mathrm{pH}$ 7. The filtrate was then centrifuged at $16,000 \mathrm{rpm}$ for 15 minutes at $4^{\circ} \mathrm{C}$. The resulting filtrate is used as a source of enzymes. $2.0 \mathrm{ml}$ of $3 \mathrm{mM}$ L-phenylalanine solution was added with $0.9 \mathrm{ml}$ of deionized water and mixed until homogeneous (Karthikeyan et al., 2006). 
PAL activity was measured by a modified method of Sainders and McClure (1975). The reaction was carried out for 60 minutes at $37^{\circ} \mathrm{C}$ and an increase in absorbance at A290 nm were recorded at 15 min intervals. $200 \mathrm{mM}$ Tris$\mathrm{HCl}(\mathrm{pH} 7.0)$ was used as a buffer solution and $20 \mathrm{mM} \mathrm{L}-$ phenylalanine as the enzyme test substrate. The rate curve of cinnamic acid formation was used as a measure of enzyme activity by using an absorbance increase of 0.01 at $290 \mathrm{~nm}$ as a cinnamic acid curve of 3.09 nmol. PAL activity was expressed in $\mu$ mol of cinnamic acid min- $1 \mathrm{~g}$ 1. Protein calibration was measured according to the Bradford (1976) standard method.

\section{INDENTATIONS AND EQUATIONS}

Tomatoes treated with PGPR showed higher defense enzyme activity when compared to controls. Peroxidase (PO) enzyme activity in tomato leaves introduced by PGPR showed a 3-4 times higher increase compared to the untreated control. Tomatoes treated with EAB 2.1 isolate showed the highest peroxidase levels with a value of $0.0009 \mu \mathrm{g} \cdot \mathrm{mL}^{-1}$ and the lowest was found in controls with a content of $0.0002 \mu \mathrm{g} \cdot \mathrm{mL}^{-1}$ (Figure 1).

Apart from the PO enzyme, giving PGPR to tomatoes also increased the activity of the PPO enzyme. The PPO enzyme activity in tomatoes treated with PGPR also showed a 0.5 -fold increase when compared to the control (Figure 2).. The highest PPO was found in plants introduced by EAB 2.1 isolate with a PPO content of 0.095 $\mu \mathrm{g} \cdot \mathrm{mL}^{-1}$, while the lowest was found in the control with a value of $0.045 \mathrm{ppm}$. All isolates used in this study showed enzyme activity above the control plants.

Furthermore, PGPR treatment on tomato plants can increase the activity of the enzyme Penylalanin Ammonia lyase. The activity of the PAL enzyme given PGPR can increase PAL by $0.17 \mu \mathrm{g} \cdot \mu \mathrm{g} \cdot \mathrm{mL}^{-1}$. The highest PAL activity was found in EAB 2.1 isolates with a value of $15.98 \mu \mathrm{g} \cdot \mathrm{mL}^{-1}$, while the lowest was found in controls with a content of $13.98 \mu \mathrm{g} \cdot \mathrm{mL}^{-1}$ (Figure 3 ). This is because PGPR can increase the level of peroxidase activity in plants.

Giving PGPR to tomato plants shows the induction mechanism of systemic resistance in tomatoes which is then expressed through the activation of defense enzymes such as PO, PPO and PAL. Ahmed et al., (2011) stated that PGPR is stimulating Systemic response in tomatoes by inducing high levels of enzymes activity of phenylalanine ammonialyase (PAL), peroxidase (PO), polyphenol oxidase (PPO) and chitinase as well as accumulation of high levels of phenolics. In the study, it was found that there was an increase in defense enzymes ISSN: 2456-1878 induced by PGPR in tomato plants with a 3-4-fold increase in PO, 0.5-fold PPO and 2-fold PAL. This was also found by Ahmed et al., (2011) who reported that the administration of PGPR $P$. puptida and P. flureccens to tomato plants could increase PAL activity 3 times, PO 2 times and PPO 2 times.

Polyphenol oxidase is a plant defense enzyme from biotic and abiotic stress. Polyphenol oxidase is an enzyme in plants that regulate feeding, growth, development of insect pests, and play a major role in plant defense against biotic and abiotic stresses (Sharma et al., 2009). PO is a group containing enzyme copper that catalyzes the oxidation of hydroxy phenols to derivative quinones, which have antimicrobial activity (Chunhua et al., 2001). In the research that has been done, the PO enzyme can increase 3-4 times and all isolates in the treatment showed enzyme activity above the control. This shows that all PGPR isolates used in this study have the potential to increase PO levels. Research conducted by Sharavankumar et al., (2006) states that giving PGPR to tea plants can increase the activity of the PPO enzyme. An increase in PO levels also occurred in rice plants treated with Baciluss spp (Rais et al., 2017).

Furthermore, there is the peroxidase enzyme which is one of the important enzymes in defense that plays a role in strengthening plant cell walls. Peroxidases produce reactions that regulate defense-related signal transduction pathways, initiate hypersensitivity reactions, and strengthen cell walls through increased lignification (Ralph et al., 2004). In the research, the peroxidase enzyme activity in untreated tomato plants was only around $0.0002 \mu \mathrm{g} \cdot \mathrm{mL}^{-1}$ whereas those treated with PGPR could reach $0.0009 \mu \mathrm{g} \cdot \mathrm{mL}^{-1}$. This indicated that there was an increase in PO activity in plants treated with PGPR and all isolates showed more increases than the control. This is also obtainedby Sarvanan et al., (2004) that the increase in PPO activity in banana tubers introduced with Psuedomonas fluorescence and suppressed fusarium wilt disease. Rice plants induced by Bacillus spp can increase polyphenol oxidase enzymes as much as 3.0-3.8 fold and can suppress development Pyricularia oryzae (Rais et al., 2017)

PAL is one of the important enzymes that play a role in other phenolic synthesis related to plant defense (Daayf et al., 1997). PAL serves as a precursor file for the biosynthesis of lignin and other phenolic compounds that accumulate in response to infection (Klessing and Melany 1994). In studies that have been carried out PAL activity on treated tomatoes can increase up to $0.17 \mu \mathrm{g} \cdot \mathrm{mL}^{-1}$ when compared to controls. Although there is only an increase $0.17 \mu \mathrm{g} \cdot \mathrm{mL}^{-1}$ but all isolates used in this study 
had the potential to increase PAL activity in tomatoes. Yanti (2015) also reported thatOnions introduced with 8 rhizobacteria isolates showed an increase in peroxidase enzyme activity in the roots and leeks, PK2Rp3 was the best isolate with an increase in enzyme activity reaching $\left(0.058 \mu \mathrm{g} \cdot \mathrm{mL}^{-1}\right)$ in roots and leaves.

IV. FIGURES AND TABLES

\section{Enzim Peroksidase}

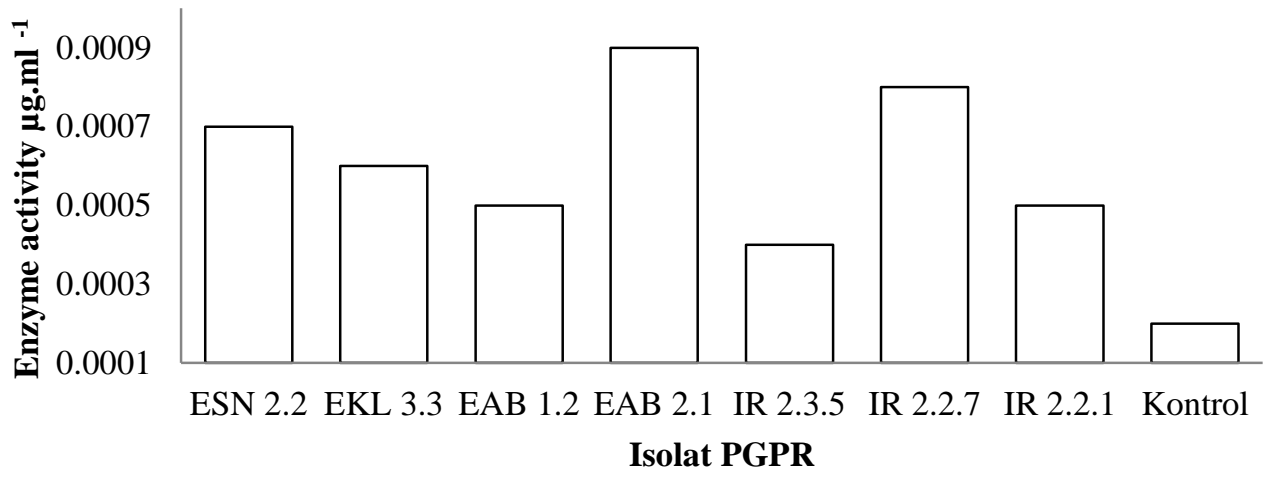

Fig.1: Production of Peroksidase in tomato plants introduced by PGPR

\section{Enzim Polifenol Oksidase (PPO)}

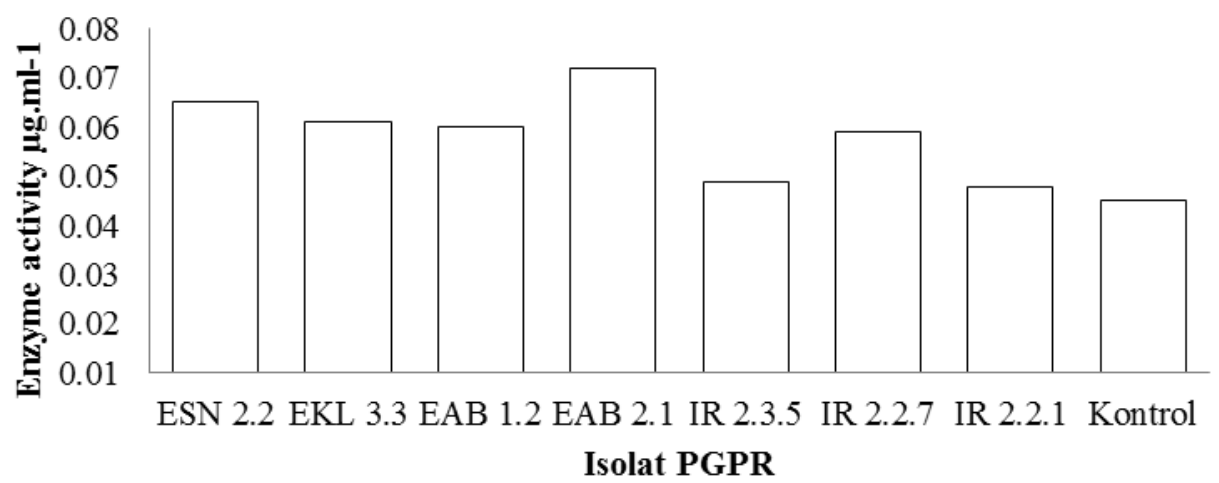

Fig.2: Production Polifenol Oksidase enzymes in tomato plants introduced by PGPR 


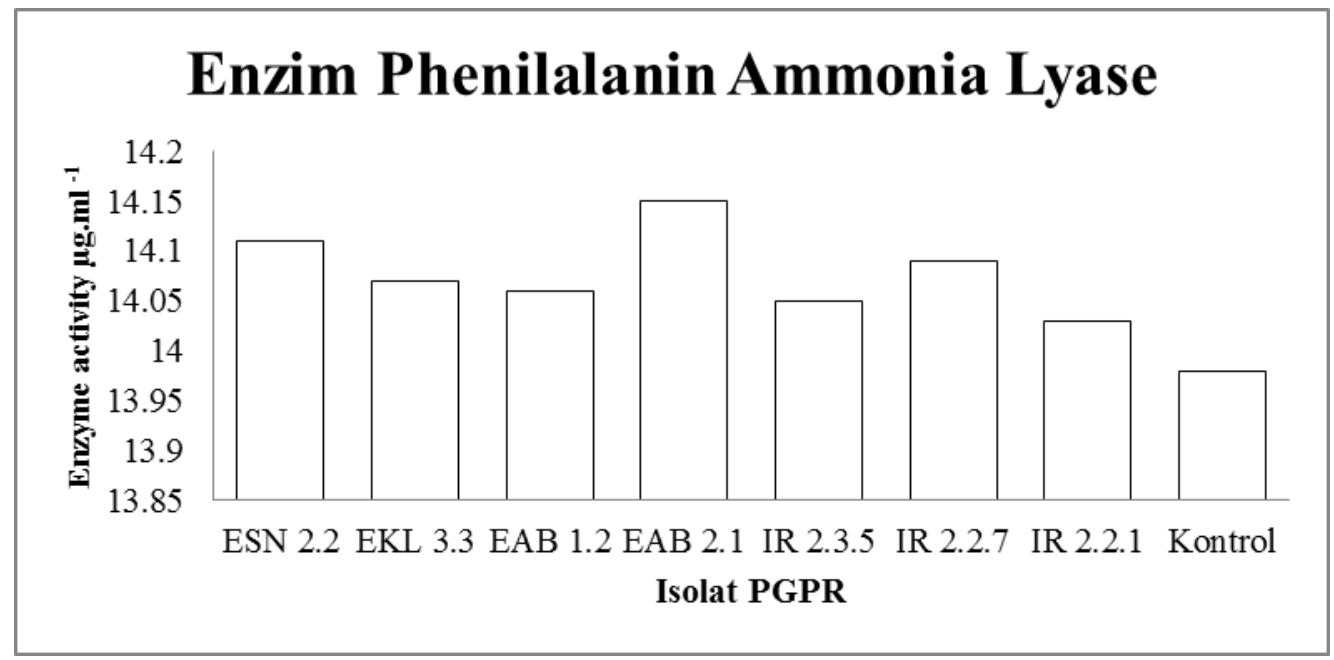

Fig.3: Production of Phenilalanan Ammonia Lyase enzymes in tomato plants introduced by PGPR

\section{CONCLUSION}

PGPR can induce plant resistance through ISR which further increases the activity of the PO, PPO and PAL enzymes. Seven isolates used in this study were able to increase the activity of the PO, PPO, and PAL enzymes, with Isolate EAB 2.1 being the best isolate in increasing enzyme activity.

\section{ACKNOWLEDGEMENTS}

This research was funded by Andalas university in accordance with contract leading applied research cluster publication acceleration to professor (PTU-KPR2GBUnand) No: T / 1 / UN.16.17 / PP. Pangan KRP2GB / LPPM / 2020 academic year 2020.

\section{REFERENCES}

[1] Adhipathi P, Nakkeeran S, Devi PR, Velazhahan R, and Raguchander T. 2014. PGPR Induced Differential Expression Of Defense Enzymes Regulating Resistance Against Colletotrichum Capsici In Turmeric. Journal of Advances In Biotechnology 4 (2): 358-371

[2] Ahmed H. E, Mohamed ZK, ElDean ME and Farahat MG. 2011. induced Sistemic Protection Against tomato leaf spot (Early Leaf Blight) and Bacterial Speack by Rhizobacterial Isolate. J. Exo.Biol 7 (1): 49-57

[3] Bateman, D.F. 1967. Increase in peroxidase desearsed plant tissue in source book of laboratory exercise in plant pathology. San Fransisco: WH Freeman and Co.

[4] Bradford, MM 1976. A rapid and sensitive method for the quantitation of microgram quantities of protein utilizing the principle of protein-dye binding. Biochem Anal 72, 248-254.

[5] Chen, C., Belanger, R., Benhamou, N. and Paulitz, TC (2000). Defense enzymes induced in cucumber roots by treatment with plant growth-promoting rhizobacteria (PGPR) and Pythium aphanidermatum. Physiol Mol Plant Pathol. 56: 13-23

[6] Chunhua, S., Ya, D., Bingle, X., Xiao, L., Yonshu, X. and Qinguang, L. (2001). The purification and spectral properties of PPO I from Nicotianan tababcum. Plant Molecular Biology. 19: 301-314

[7] Daayf, F., Schmitt, A., and Belanger, RR 1997 Evidence of phytoalexins in cucumber leaves infected with powdery mildew after treatment with Reynoutriasa chalinensis leaf extract. Plant physiology. 113: 719-727

[8] Filippi MCC, Da Silva GB, Silva-Lobo VL, CoÃrtes MVC, Moraes AJG, Prabhu AS. Leaf blast (Magnaporthe oryzae) suppression and growth promotion by rhizobacteria on aerobic rice in Brazil. Biol Control 58: 160-1666

[9] Habazar T, Nasrun, Jamsari and Rusli I. 2007. Spread Patterns of Bacterial Leaf Blight (Xanthomonas axonopodis pv. Allii) on Shallots and Control Efforts through Immunization Using Rhizobacteria. Reports on the research results of the Andalas University, Padang with the KKP3T Agricultural Research and Development Project.

[10] Hatami M, Ghorbanpour M (2016) Changes in phytochemicals in response to rhizospheric microorganism infection. In: Choudhary D, Varma A (eds) Microbialmediated induced systemic resistance in plants. Springer, Singapore

[11] Jetiyanon K. 2007. Enzyme responses related to defense in plants treated with a mixture of Bacillus strains (IN937a and IN937b) against different pathogens. Biol. Control, 42: $178-185$

[12] Khalimi K and Wirya G. 2009. Using Plant growth promoting rhizobacteria for biostimulants and bioprotectants. J. Ecotrophic. 131-135

[13] Karthikeyan, M, Radhika, K, Mathiyazhagan, S, Bhaskaran, R, Samiyappan R., Velazhahan R. 2006. Induction of phenolics and defense-related enzymes in 
coconut (Cocos nucifera L.) roots treated with biocontrol agents. Brazilian Journal of Plant Physiology, 18(3): 367377

[14] Klement Z, Rudolph K, and Sand DC. 1990. Methods in Phytobacteriology. Kiado Academy, Budapest.

[15] Klessing, DF, and Melany, A. 1994 Signaling of salicylic acid in plants. Plant molecular biology. 26: 1439-1458

[16] Meziane H, Van der Sluis I, Van Loon LC, Hofte M, Bakker PAHM. 2005. Determinants Pseudomonas putida WCS358 are involved in inducing systemic resistance in plants. Mol. Pathol Plant., 6: 177-185

[17] Rais A, Jabeen Z, Shair F, Hafeez FY, Hassan MN. 2017.Bacillus spp., a bio-control agent enhances the activity of antioxidant defense enzymes in rice against Pyricularia oryzae. Plos one 1-17

[18] Ralph J, Lundquist K, Brunow G, Lu F, Kim H, Schatz PF, Marita JM, Hatfield RD, Ralph SA, Christensen JH. 2004. Lignins: natural polymers from oxidative coupling of 4-hydroxyphenylpropanoids. Phytochem Rev 3: 29-60

[19] Sainders, J. A., McClure, J. W. 1975. Phytochrome controlled phenylalanine ammonia lyase in Hordeum vulgare plastids. Phytochemistry, 14(5-6): 1285-1289

[20] Sarvanan, T., Bhaskaran, R. and Muthuswamy, M. (2004). Pseudomonas fluorescence induced enzymological changes in banana roots (cv. Rasthali) against fusarium wilt disease. Plant Pathology Journal. 3 (2): 72-70

[21] Saravanakumar D, Vijaykumar C, Kumar N, and Samiyapan R. 2007. PGPR induced Defense Response in The tea Plant Against Blister Blight disease. ScientsDirect Crop Protection 26: 556-565

[22] Sharma, SD., P. Kumar, H. Raj \& S. Bhardwaj. 2009. Isolation of arbuscular mycorrhizal fungi and Azotobacter chroococcum from local litchi orchards and evaluation of their activity in the air layers system. Scientia Horticulturae. 6: 117-123.

[23] Yanti Y. 2015. Peroxidase Enzyme Activity of Rhizobacteria-Introduced Shallots Bulbs to Induce Resistance of Shallot towards Bacterial Leaf Blight (Xanthomonas axonopodis pv allii). ScientDirect Procedia Chemistry 14: $501-507$

[24] Yanti, Y, Warnita, Reflin, and Busniah M. 2017. Identification and Characterization of Potential Indegenous Endophytic Bacteria which had Ability to Promote Growth Rate Of Tomatoes And Biocontrol Agent of Ralstonia solanacearum and Fusarium oxysporum fsp. solani. Indonesian Journal of Microbiolgy 11 (4)

[25] Yanti, Y, Warnita, Reflin, Hamid, H. 2018. Short Communication: Development of selected PGPR consortium to control Ralstonia syzygii subsp. indonesiensis and promote the growth of tomato. Biodiversitas. Volume 19, Number 6. 